\title{
DETERMINANTS OF LEVERAGE AND REGULATION: AN ANALYSIS IN DENTAL HEALTH PLAN OPERATORS
}

\author{
DETERMINANTES DO ENDIVIDAMENTO E REGULAÇÃO: \\ UMA ANÁLISE EM OPERADORAS DE PLANOS DE \\ SAUUDE EXCLUSIVAMENTE ODONTOLÓGICOS
}

\author{
Ewerton Alex Avelar ${ }^{1}$ \\ Antônio Artur de Souza ${ }^{1}$ \\ Hudson Fernandes Amaral ${ }^{2}$ \\ Jacqueline Braga Paiva Orefici ${ }^{1}$ \\ Romain Cailleau ${ }^{3}$ \\ 1 Federal University of Minas Gerais - UFMG, Faculdade de Ciências Econômicas, Departamento de Ciências Contábeis, Belo Horizonte, Minas Gerais, Brazil \\ 2 Centro Universitário Unihorizontes, Programa de Mestrado em Administração, Belo Horizonte, Minas Gerais, Brazil \\ 3 Federal University of Minas Gerais - UFMG, Centro de Pós-Graduação e Pesquisas em Administração, Faculdade de Ciências Econômicas, Belo Horizonte, Minas Gerais, Brazil
}

\begin{abstract}
Purpose - This paper examines the determinants of debt levels of Brazilian dental health plan operators (OPS) under the National Supplementary Health Agency (ANS) regulation.

Design/methodology/approach - It is an empirical article based on quantitative and causal research. The sample consisted of data from 2010 to 2018 available on the ANS website. The techniques of content analysis, descriptive statistics and panel regression were used for data analysis.

Findings - We found that several variables related to the ANS regulation influence dental OPS debt levels. Furthermore, there are also several similarities between the two categories under analysis: dental cooperatives and group dentistry, despite the differences in the legal nature of such organizations.

Research limitations/implications - The present study suffers from some limitations: (a) the sample investigated is restricted to OPS public data; and (b) regulation variables are limited due to the data available for calculation, despite our efforts to show otherwise.

Originality/value - The present research offers a range of contributions to the literature on dental operators' capital structure. Firstly, it emphasized the impact of regulation in dental operators' financial decisions in Brazil. Moreover, it confirmed the important role of companies' determinant variables of capital structure in explaining OPS debt levels. Lastly, the study introduced regulatory variables as determinants of OPS debt ratios. Keywords: Leverage determinants; Dental health plan operators; National Supplementary Health Agency (ANS); Regulation.
\end{abstract}




\section{RESUMO}

Objetivo - Analisar os determinantes do endividamento de operadoras de planos de saúde (OPS) exclusivamente odontológicos (EO), sob a perspectiva da regulação da Agência Nacional de Saúde Suplementar (ANS). Metodologia - Pesquisa quantitativa e causal. A amostra consistiu nas OPS cujos dados de 2010 a 2018 estavam disponíveis no site da ANS. Foram usadas para a análise dos dados as técnicas de análise de conteúdo, estatística descritiva e regressão com dados em painel.

Conclusão - Constatou-se que diversas variáveis relacionadas à regulação da ANS influenciaram os níveis de endividamento das OPS odontológicas. Ademais, observaram-se várias semelhanças entre as duas categorias em análise (cooperativas odontológicas e odontologia de grupo), apesar das diferenças na natureza jurídica de tais organizações.

Limitações - O estudo apresenta algumas limitações: (a) a amostra investigada restringe-se a dados públicos de OPS; e (b) as variáveis de regulação são limitadas devido aos dados disponíveis para cálculo.

Originalidade / valor - Este artigo apresenta uma série de contribuições para a literatura sobre a estrutura de capital de OPS EO. Primeiramente, destacou-se o papel da regulação nas decisões financeiras das OPS no Brasil. Ademais, confirmou-se a importância de variáveis determinantes da estrutura de capital de empresas para explicar o endividamento das OPS. Por fim, foram propostas variáveis regulatórias como determinantes do endividamento dessas organizações.

Palavras-chaves: Determinantes do endividamento; Operadoras de planos de saúde (OPS) exclusivamente odontológicos; Agência Nacional de Saúde Suplementar (ANS); Regulação.

\section{INTRODUCTION}

Studies on corporate capital structure are among the most relevant in finance, with several theoretical approaches being discussed and tested in the finance literature (An, 2002). Brito, Corrar, and Batistella (2007) point out that the development of empirical studies emphasizes the use of variables (henceforth "determinant variables") to determine corporate debt levels.

Among the key determinants used in several national and international studies, the following ones should be mentioned: asset tangibility, organization size, profitability/returns, growth, singularity, non-debt tax benefits, taxation, and risk (Cavalcanti, Castro, Avelar, Lazo \& Mól, 2016; Correa, Basso, \& Nakamura, 2013; Forte, Barros, \& Nakamura, 2013; Frank \& Goyal, 2009; Perobelli \& Fama, 2002; Pohlmann \& ludícibus, 2010; Rajan \& Zingales, 1995; Titman \& Wessels, 1988).

However, despite the importance given to financing decisions and their impact on firm leverage, health plan operators (OPS) remain relatively unexplored in Brazil. The National Supplementary Health Agency (ANS, 2017) and Bragança (2017) affirm that OPS are essential organizations for the Brazilian healthcare system since OPS serve tens of millions of people. Indeed, dental OPS have grown over $700.0 \%$ in terms of health plan beneficiaries since 2000 (ANS, 2018c). Still, many of these organizations experience economic and financial management problems, as shown by the Brazilian Association of Group Medicine - ABRAMGE (2015) and Xavier (2017). In addition, health plan operators' financial decisions are significantly influenced by National Supplementary Health Agency (ANS) strict regulations (Pinheiro, Peleias, Silva \& Martins, 2015; Silva \& Loebel, 2016).

Given the above considerations, the present research aims at analyzing the determinants of debt levels of Brazilian dental OPS under the ANS regulation. To this end, the following specific objectives are proposed: (a) to identify regulatory ANS variables that have the potential to determine the debt ratios of dental OPS; and (b) to estimate models that can show the relationship between operators' debt ratios and the selected variables.

Researches that focus on analyzing aspects related to dental operators' financial decisions are relevant in several ways. ANS data (2018c) indicate that over 47 million health plan beneficiaries use the supplementary health system - nearly $23.0 \%$ of the Brazilian population. While dental 
OPS serve nearly 22 million people (ANS, 2018c), they keep experiencing management problems (ABRAMGE, 2015; Xavier, 2017). In addition to existing challenges faced by health operators in Brazil, Varella and Ceschin (2014) emphasize that operators' unchanged behavior and regulation only exacerbate the already problematic situation. Moreover, it is important to note that there are no studies linking regulatory variables to dental operators' leverage. Therefore, the present research contributes to fill this gap.

\section{LITERATURE REVIEW}

\subsection{Determinant Variables of Debt Levels}

Ross, Westerfield, Jaffe and Lamb (2015) assert that financing decisions are related to the proportion of shareholders' equity and liabilities in a firm's capital structure, with a focus on its leverage. Fama and French (2005) point out that the modern literature on corporate finance is mainly focused on two competing theories to explain corporate debt levels, namely: the trade-off theory (TOT) and the pecking order theory (POT). While the first theory states that an organization's debt level is determined by the mean value of the tax benefits and the costs of financial distress, the second one provides an order of preference for the use of corporate resources: (1) internally generated cash; (2) debts; and (3) equity (Ross et al., 2015). In this paper, we focus on the TOT, because it does not require any assumptions about new stock issues, as does the POT (Myers, 1984). It is important to note that the most part of studied organizations are private ones, thus, TOT seems a better theory in order to analyzing the phenomenon.

Brito, Corrar, and Batistella (2007) state that capital structure theories were developed along with a series of national and international empirical research that aim at identifying such primary variables for determining firms' debt levels as tangible assets, company size, profitability/ returns, growth, singularity, non-debt tax benefits, taxation, and risk. Asset tangibility is a variable that usually affects corporate debt levels. According to Rajan e Zingales (1995), firms with a higher proportion of tangible assets, offered as collateral in loans, tend to have higher leverage. In the same way, size is a variable that can influence the leverage level since large companies are susceptible to more diversification and they have a better reputation in the credit market, as argued by Frank and Goyal (2009).

Profitability/returns and growth are critical variables to understand corporate leverage (Fama \& French, 2005). It is expected that profitable companies have higher levels of debt due to their capacity of generating resources to payoff dividends (Pohlmann \& ludícibus, 2010). On the other hand, growing companies have lower debt levels, because they are riskier than the mature ones (Brito et al., 2007).

Singularity refers to specific aspects that make a company unique. Perobelli and Fama (2002) posit that companies holding a high degree of singularity are expected to generate high costs for society when they are liquidated. Such companies are also expected to be more conservative, preventing them from developing high levels of debt.

As regards the taxation, Pohlmann and ludícibus (2010) show that higher profit taxes tend to increase firms' debt levels. Regarding non-debt tax benefits, Titman and Wessels (1988) state that higher deduction volumes (e.g., depreciation and amortization) tend to increase corporate debt levels. Finally, the risk variable is negatively related to debt levels (Forte et al., 2013; Ross et al., 2015). Table 1 presents the operationalization of variables used in our econometric models and based on several national and international studies. 
Table 1. Debt-related variables in empirical studies.

\begin{tabular}{|c|c|c|c|}
\hline Variable & Abbreviation & Calculation & References \\
\hline General indebtedness & GI & $\begin{array}{l}(\mathrm{CL}+\mathrm{NCL}) \div \\
\mathrm{TA}\end{array}$ & $\begin{array}{l}\text { Brito, Corrar and Batistella (2007), Ceretta, } \\
\text { Vieira, Fonseca \& Trindade (2009), Correa et al. } \\
\text { (2013), Forte, Barros and Nakamura (2013) e } \\
\text { Avelar, Cavalcanti, Pereira \& Boina (2017). }\end{array}$ \\
\hline Short-term debt & STD & $\mathrm{CL} \div \mathrm{TA}$ & $\begin{array}{l}\text { Brito et al. (2007), Forte et al. (2013) e Avelar et } \\
\text { al. (2017). }\end{array}$ \\
\hline Long-term debt & LTD & $\mathrm{NCL} \div \mathrm{TA}$ & Brito et al. (2007) e Avelar et al. (2017). \\
\hline Tangibility & TAN & $\mathrm{FA} \div \mathrm{TA}$ & $\begin{array}{l}\text { Rajan and Zingales (1995), Brito et al. (2007) e } \\
\text { Ceretta et al. (2009). }\end{array}$ \\
\hline Size & OPSS & $\ln (\mathrm{TA})$ & $\begin{array}{l}\text { Fama and French (2002), Lemmon and Zender } \\
\text { (2010) e Forte at al. (2013). }\end{array}$ \\
\hline Profitability/returns & PRO & $\mathrm{EBIT} \div \mathrm{NR}$ & $\begin{array}{l}\text { Titman and Wessels (1988), Perobelli and Fama } \\
\text { (2002) e Pohlmann and Iudícibus (2010). }\end{array}$ \\
\hline Growth & GROW & $\left(\mathrm{TA}_{\mathrm{t}+1}-\mathrm{TA}_{\mathrm{t}}\right) \div$ & $\begin{array}{l}\text { Titman and Wessels (1988), Perobelli e Fama } \\
\text { (2002), Fama and French (2005), Leal (2008), } \\
\text { Forte et al. (2013) e Avelar et al. (2017). }\end{array}$ \\
\hline Non-debt tax shield & NDTS & $\begin{array}{l}(\mathrm{DEP}+\mathrm{AMOR}) \\
\div \mathrm{TA}\end{array}$ & Ceretta et al. (2009) \\
\hline Singularity & SIN & $\mathrm{INT} \div \mathrm{TA}$ & $\begin{array}{l}\text { Titman and Wessels (1988), Perobelli and Fama } \\
\text { (2002) e Avelar et al. (2017). }\end{array}$ \\
\hline Taxation & TAX & $\mathrm{IT} \div \mathrm{NR}$ & Pohlmann and Iudícibus (2010) \\
\hline Risk & RIS & $\mathrm{CA} \div \mathrm{CL}$ & Leal (2008) e Ceretta et al. (2009). \\
\hline
\end{tabular}

Notes: CA - Current Assets; CL - Current Liabilities; NCL - Non-current Liabilities; NR - Net Revenue; TA - Total Asset; CGS - Cost of Goods Sold; NW - Net Worth; EBIT - Earnings Before Interest and Taxes; FA - Fixed Assets; DEP - Depreciations; AMOR - Amortizations; INT - Intangible Assets; IT - Income tax.

When the debt variable was operationalized, we decided to adopt what Rajan and Zingales (1995) call an expanded definition of leverage; which is a calculation of total liabilities (both onerous and non-onerous) divided by total assets. According to these authors, a more appropriate definition for leverage would only consider the costly liabilities in this calculation. However, due to the data collected in our study, we chose to use the broader definition, as defined by Rajan and Zingales (1995). For the operators analyzed, less than $10.0 \%$ of their liabilities were found onerous. In addition, the broader definition of leverage has been adopted by several researchers, such as Avelar, Cavalcanti, Pereira and Boina (2017), Brito et al. (2007), Ceretta et al. (2009), and Correa et al. (2013).

Furthermore, authors such as Cavalcanti et al. (2016) and Welch (2011) reiterate the importance of using variables that can determine debt level according to debt temporality. In other words, certain variables would be more relevant to explain short-term debt, while others would be better suited to explain long-term debt (Cavalcanti et al., 2016).

Finally, several national and international authors emphasize that the regulation of specific economic sectors also influences debt levels (see e.g., Fama \& French, 2002; Lemon \& Zender, 2010; Pinheiro et al., 2015). The ANS regulation on OPS tends to have a significant impact on their economic results, as argued by Leal (2014). The following section offers a detailed discussion about this aspect.

\subsection{The ANS Regulation of Health Plan Operators}

OPS are companies that offer their customers a comprehensive set of healthcare services

Rev. AdM. UFSM, SANTA MARIA, V. 13, NÚMERo 4, P. 808-828, 2020

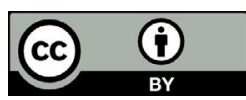


based on monthly fixed payments (Engberg, Wholey, Feldman \& Christianson, 2004). Costa (2008) states that the Brazilian market for private health plans was developed in an institutional context of low regulation, without fiscal incentives or barriers, up until the late 1990s. This market was only effectively regulated in 1998 with the Law n. 9656 of 1998, which started controlling operators' operations and performance (Law n. 9656, 1998).

According to Menezes et al. (2016), the legislation to regulate OPS emerged in response to operators' abusive actions to mitigate risks and increase profitability and to high demand by consumers, medical entities, and health secretariats. The ANS was created in this context through a Provisional Measure in 1999 (Fernandes, Ferreira \& Rodrigues, 2014), which was later converted into the Law n. 9961. Veloso and Malik (2010) argue that the ANS regulation led to restrictions on premium increases, standardization of service coverage, lower differentiation between OPS, and extended customer rights.

The ANS categorizes Brazilian OPS into different types, namely: administrator, medical cooperative, dental cooperative, self-managed, group medicine, group dentistry, and philanthropy (ANS, 2000). According to the aforementioned resolution, non-profit organizations are constituted according to the provisions of Law $n .5764$ of 1971, which establishes the legal regime of cooperative societies in Brazil, including dental cooperatives that operate exclusively with dental health plans. Companies or any other entities that offer dental health plans but do not fit in the definition of a cooperative are categorized as group dentistry (ANS, 2000). This paper focuses on dental OPS; that is, OPS classified as either dental cooperatives or group dentistry. Table 2 shows the number of beneficiaries of these categories from 2000 to 2016.

Table 2. Number of health plan beneficiaries from December 2000 to December 2016

\begin{tabular}{|c|c|c|}
\hline \multirow[t]{2}{*}{ Competence } & \multicolumn{2}{|c|}{ Number of beneficiaries } \\
\hline & Medical assistance with or without dentistry & Exclusively dental \\
\hline 2000 & 31.161 .481 & 2.603 .001 \\
\hline 2001 & 31.727 .080 & 3.062 .681 \\
\hline 2002 & 31.513 .309 & 3.677 .782 \\
\hline 2003 & 32.074 .667 & 4.325 .568 \\
\hline 2004 & 33.840 .716 & 5.312 .915 \\
\hline 2005 & 35.441 .349 & 6.204 .404 \\
\hline 2006 & 37.248 .388 & 7.349 .643 \\
\hline 2007 & 39.316 .313 & 9.164 .386 \\
\hline 2008 & 41.468 .019 & 11.061 .362 \\
\hline 2009 & 42.561 .398 & 13.253 .744 \\
\hline 2010 & 44.937 .350 & 14.514 .074 \\
\hline 2011 & 46.025 .814 & 16.669 .935 \\
\hline 2012 & 47.814 .411 & 18.525 .537 \\
\hline 2013 & 49.435 .589 & 19.569 .252 \\
\hline 2014 & 50.409 .378 & 20.325 .917 \\
\hline 2015 & 49.259 .250 & 21.162 .599 \\
\hline 2016 & 47.740 .783 & 21.970 .649 \\
\hline
\end{tabular}

Note: Adapted from “Sala de Situação" (ANS, 2018c). 
Table 2 shows a tremendous evolution in the number of dental health plan beneficiaries in relation to the general health insurance market in Brazil. While there was a $53.2 \%$ increase in the number of beneficiaries for all OPS categories between 2000 and 2016, the number of dental health plan beneficiaries increased by $744.1 \%$ in the same period (ANS, 2018c).

\subsection{Research Hypotheses}

In this section, we present the research hypotheses related to the ANS-imposed regulation that have the potential to influence the financing decisions made by OPS managers, according to previous literature. According to the Unconstitutionality Suit No. 1931 of 2003, health plans established prior to the ANS regulation (known as "old plans") remain valid and are not subject to newer regulation (Supremo Tribunal Federal, 2003). Since OPS could negotiate these contracts according to their objectives and market situations, they had a wider range of profitable strategies. That implies in higher levels of debt based on the TOT. Thus, we hypothesize that:

Hypothesis 1 The leverage of dental OPS is positively related to the proportion of old OPS contracts.

The pricing of individual health plans must be set according to the ANS rules since it represents a major decision for OPS. For elderly people, the ANS requires that adjustments of health plans be restricted to a fixed value against that of the first age group, which is necessarily the cheapest. According to Kudlawicz, Steiner, and Frega (2015), such restrictions can lead to reduced OPS profits. While OPS suffer from increased costs due to the broader range of services provided to elderly people, they cannot increase their monthly rate accordingly. It is important to note that the average of beneficiaries is an information published by ANS (2016). As such, in according to TOT, the second hypothesis is as follows:

\begin{tabular}{l|l} 
Hypothesis 2 & The average age of beneficiaries is negatively related to dental OPS debt levels.
\end{tabular}

The readjustment of individual health plans is different from that of collective ones, which are linked to companies and other organizations. Varella and Ceschin (2014) affirm that, while individual plans can only be readjusted through ANS authorization, collective plans are adjusted to some extent following negotiations between the parties involved. OPS, therefore, tend to prefer joint rather than individual plans, as stated by Leal (2014). They are also expected to reflect pricing changes according to their interests. Thus, they are expected to present higher levels of both profit and debt, according to the TOT. Based on these assumptions, the third hypothesis appears as:

\begin{tabular}{|l|l|}
\hline Hypothesis 3 & $\begin{array}{l}\text { The proportion of beneficiaries of OPS collective plans is positively related to the leverage } \\
\text { of dental OPS. }\end{array}$ \\
\hline
\end{tabular}

Baldassare (2014) asserts that the ANS takes into consideration the OPS size in its norms, categorizing smaller OPS as more critical due to capillarity. This author adds that the agency develops regulations aimed at reducing the administrative expenses of smaller operators, especially in relation to their economic and financial requirements. On the other hand, Frank and Goyal (2009) state that large organizations could obtain more debt due their higher reputation and diversification. With these careful considerations, we develop the fourth hypothesis: 
According to the OPS operating region, the ANS requires different levels of minimum corporate funds (Adjusted Shareholder Equity, or Adjusted Net Worth - ANW), as well as specific technical provisions, in accordance with the Normative Instruction 209/2009 (ANS, 2009). The six ANS regions described in the aforementioned resolution are presented in Table 3. The ANW is the minimum capital requirement that health plan operators must have to operate in a given area, regardless of their size. Technical provisions represent the expected risk, measured following previously set business criteria, and require such real guarantees as real estate or bonds (Pinheiro et al., 2015). Given that those considerations relate to OPS asset level, we establish the fifth hypothesis:

\section{\begin{tabular}{l|l} 
Hypothesis 5 & Dental OPS debt levels depend on firms' operating region.
\end{tabular}}

Table 3. Operating regions of OPS

\begin{tabular}{|c|l|}
\hline Region & \multicolumn{1}{c|}{ Description } \\
\hline 1 & $\begin{array}{l}\text { OPS that operate throughout the national territory or in groups of at least three states among the } \\
\text { following: São Paulo, Rio de Janeiro, Minas Gerais, Rio Grande do Sul, Paraná and Bahia. }\end{array}$ \\
\hline 2 & $\begin{array}{l}\text { OPS operating in the State of São Paulo or in more than one state, with the exception of the groups } \\
\text { defined in the criterion of Region 1. }\end{array}$ \\
\hline 3 & OPS that operate in a single state, whatever it may be, except in the State of São Paulo. \\
\hline 4 & $\begin{array}{l}\text { OPS that operate in the Municipality of São Paulo, Rio de Janeiro, Belo Horizonte, Porto Alegre, } \\
\text { Curitiba or Brasília. }\end{array}$ \\
\hline 5 & OPS that operate in a group of municipalities, except those defined in Region 4. \\
\hline 6 & OPS that operate in a single municipality, except those defined in Region 4. \\
\hline
\end{tabular}

Note: Adapted from “Resolução Normativa - RN n. 209” (ANS, 2009).

Silva, Costa, Abbas and Galdamez (2017) affirm that the Supplementary Health Performance Index (SHPI) is the primary instrument adopted in the evaluation program of OPS in Brazil, and it is used to measure operators' performance. According to the ANS (2015), the SHPI is calculated based upon a set of indicators defined by the ANS and permanently assessed for improvements in the Operator Qualification Program. The SHPI simultaneously evaluates a series of aspects related to operators' obligations (operational, health, consumer satisfaction, relationship with SUS, etc.) (ANS, 2018a). To achieve best results on all SHPI indexes, operators are supposed to carry out a series of extra activities using expenditures. This implies in lower levels of both profit and leverage, in accordance to the TOT. Consequently, the sixth hypothesis is given by:

\begin{tabular}{|l|l} 
Hypothesis 6 & The SHPI of OPS is negatively related to the leverage of dental OPS.
\end{tabular}

Another important aspect of the ANS regulation is the OPS fiscal management regime established by the ANS. Bragança (2017) states that this regime requires an ANS-designated Fiscal Director who requests the OPS remuneration paid to the professional involved in tax management. Hence, operators that have already undergone a budgetary management regime will have their financial decisions closely aligned with the ANS regulation. As this agency is prone to impose a conservative behavior over the OPS, one can expect a low risk behavior from those organizations and, consequently a low debt level. Based on the above, the seventh hypothesis is:

\begin{tabular}{l|l} 
Hypothesis 7 & OPS debt levels are negatively related to the OPS budgetary management regime.
\end{tabular} 
As previously discussed, the ANS was founded in 2000 by Law n. 9961 that "authorizes the registration and operation of private health plan operators, as well as their divestiture, merger, acquisition, alteration or transfer of corporate control" (Law n. 9961, 2000). According to the ANS (2018b), a multiple-step registration process is required. Veloso and Malik (2010) state that the ANS foundation promoted changes in the relationship of the OPS. However, no specific limits had been set for operators prior to the ANS creation (Ugá et al., 2008). Thus, considering that the old organizations have a wide range of more profitable alternatives in comparison to the newer ones, we propose the eighth hypothesis as follows:

\section{\begin{tabular}{l|l} 
Hypothesis $\mathbf{8}$ & The leverage of dental OPS is negatively related with the fact that OPS registered after \\
\hline
\end{tabular} the creation of the ANS.}

Dependency correlation refers to "the percentage correlation between the number of children under 15 added to 60+ elders, over beneficiaries between 15 and 59 years of age" (ANS, 2016 , p. 4). Since a higher demand for medical care is expected for children and the elderly, the dependency correlation is prone to influence debt ratios. This information complements the average of age of beneficiaries because it computes the effects of younger ones on medical costs. Lower profits and debt levels are expected from OPS with higher dependency correlation. That leads us to the ninth hypothesis:

\begin{tabular}{l|l} 
Hypothesis 9 & OPS dependency correlation is negatively correlated to dental OPS debt ratios.
\end{tabular}

In order to test each hypothesis in an econometric model, we need to define the variables to be used. Table 4 presents the variables that we use to test the above-mentioned hypotheses.

Table 4. Operationalization of variables related to regulation.

\begin{tabular}{|c|c|c|c|c|}
\hline Hip & Variable & Abbreviation & Calculation & References \\
\hline 1 & $\begin{array}{l}\text { Proportion of an- } \\
\text { tique contracts }\end{array}$ & ANT & $\mathrm{OPB} \div \mathrm{TOB}$ & ANS (2018b) \\
\hline 2 & $\begin{array}{l}\text { Average age of } \\
\text { beneficiaries }\end{array}$ & $\mathrm{AAB}$ & & ANS (2016) \\
\hline 3 & $\begin{array}{l}\% \text { of beneficiaries } \\
\text { of collective plans }\end{array}$ & $\mathrm{COL}$ & $\mathrm{BCOL} \div(\mathrm{BCOL}+\mathrm{BIP})$ & $\begin{array}{l}\text { Adapted from ANS } \\
\text { (2016) }\end{array}$ \\
\hline 4 & OPS size & OPSS & $\operatorname{Ln}$ (Asset) & $\begin{array}{l}\text { Baldassare (2014) } \\
\text { and ANS (2011) }\end{array}$ \\
\hline 5 & OPS action region & $\mathrm{ARC}$ & $\begin{array}{l}\text { If the operator operates in a given region } \\
(1 \text { to } 5), 1 \text {; if not, } 0 . \text { (Dummy variable) }\end{array}$ & ANS (2009) \\
\hline 6 & SHPI & SHPI & Value from 0 to 1 & ANS (2016) \\
\hline 7 & Fiscal direction & FD & $\begin{array}{l}\text { If the operator had already passed the } \\
\text { ANS tax management regime, } 0 \text {; If not, } \\
\text { 1. (Dummy variable })\end{array}$ & $\begin{array}{l}\text { Law of Access to In- } \\
\text { formation (LAI) }\end{array}$ \\
\hline 8 & ANS Registration & ANSR & $\begin{array}{l}\text { If the operator was registered before the } \\
\text { creation of ANS, 0; If not, 1. (Dummy } \\
\text { variable) }\end{array}$ & LAI \\
\hline 9 & Dependency reason & DEP & $\mathrm{U} 15 \mathrm{O} 60 \div \mathrm{A} 15 \mathrm{U} 60$ & ANS (2016) \\
\hline
\end{tabular}

Notes: OPB - Old plan beneficiaries; TOB - Total beneficiaries; U15O60 - Beneficiaries under 15 and over 60; A15U60 Beneficiaries over 15 and under 60; BCOL - Beneficiaries of collective plans; BIP - Beneficiaries of individual plans; NA - Not applicable. 


\section{METHODOLOGY}

The research presented in this article can be classified as quantitative and causal, as defined by Malhotra and Birks (2007). Our sample consists of dental OPS with their respective financial and operational data during the study period, from 2010 to 2018. Such data is publicly available on the ANS website. The choice of the operators' modality lies on the large number of beneficiaries contemplated, as well as the OPS' steady growth in recent years, as highlighted in the Section 2.2 of this paper. Table 5 exhibits the number of OPS present in the sample.

Table 5. Number of dental OPS composing the sample

\begin{tabular}{c|ccccccccc|c}
\hline OPS Modalities & $\mathbf{2 0 1 0}$ & $\mathbf{2 0 1 1}$ & $\mathbf{2 0 1 2}$ & $\mathbf{2 0 1 3}$ & $\mathbf{2 0 1 4}$ & $\mathbf{2 0 1 5}$ & $\mathbf{2 0 1 6}$ & $\mathbf{2 0 1 7}$ & $\mathbf{2 0 1 8}$ & Total \\
\hline Dental cooperative & 93 & 95 & 94 & 95 & 101 & 99 & 96 & 29 & 28 & $\mathbf{7 3 0}$ \\
Group Dentistry & 76 & 63 & 67 & 70 & 83 & 81 & 79 & 40 & 38 & $\mathbf{5 9 7}$ \\
\hline Total & $\mathbf{1 6 9}$ & $\mathbf{1 5 8}$ & $\mathbf{1 6 1}$ & $\mathbf{1 6 5}$ & $\mathbf{1 8 4}$ & $\mathbf{1 8 0}$ & $\mathbf{1 7 5}$ & $\mathbf{6 9}$ & $\mathbf{6 6}$ & $\mathbf{1 3 2 7}$ \\
\hline
\end{tabular}

There was a significant convergence between Brazilian accounting standards and international accounting standards (International Financial Reporting Standards - IFRS) in 2010 that had a significant impact on the financial information reported by operators (Gelbeck, Santos, ludícibus \& Martins, 2018). Furthermore, the data was available up to 2018. As such, the study period ranges from 2010 to 2018.

This research also uses secondary data. Financial data comes from financial statements published by the operators included in the sample. Some of the operational data are obtained from direct requests to the ANS, following Law n. 12527 of 2011 for information request (known as LAI). Since the ANS issued norms that substantially altered operator's accounting plans during the period of analysis, namely Normative Instruction (NI) 46, NR 290, and NR 314, we standardize all accounting data on an account plan used to calculate variables. For this purpose, we study the different ANS rules that were issued. We also make several revisions to ensure the integrity of the data under analysis.

Since a lot of data on non-current liabilities is missing, we computed such values (when possible) using the data on asset, current liabilities, and equity. We then computed dependent variables shown in Table 1 and in Table 4. After computing the different variables, we filtered out rows with missing values of the dependent variables. We further excluded infinite values in the data (PRO and RIS) and negative values of strictly positive variables. It is important to note that we did not exclude observations with negative net equity as such observations correspond to companies that underwent the ANS tax management regime. Finally, when outliers become a hindrance, we cleaned them using the interquartile range (IQR) given by the difference between the third quartile (Q3) and the first one (Q1). Correspondingly, we excluded observations that present a value either lower than Q1 minus 1.5 times IQR or higher than Q3 plus 1.5 times IQR. While Baldassare (2014) offers a different method based on the mean and standard deviations from the mean, we could not apply this method in our sample because outliers are so extreme that they distort descriptive statistics and the resulting cleaning process.

We then use the following methods to analyze the data: documentary analysis, descriptive statistics, and panel regression. Documentary analysis can be performed from any written record or magnetic medium used as a source of information (Bardin, 2002). We apply this technique to legislation and standards related to supplementary health in order to identify variables that could influence the OPS leverage level. Descriptive statistics present quantitative descriptions in a manageable 
way, sometimes singling out variables and, at other times, linking one variable to the other by means of associations (Babbie, 1999). In this study, we employ descriptive statistics to analyze information about central tendency measures, as well as to verify the dispersion and correlation between the examined variables of dental OPS.

Finally, in relation to panel regression, Fávero (2015) states that such a technique allows a further understanding of the behavior of the phenomena under investigation, considering characteristics and other observable units over a time period. The author highlights the three main approaches to panel data analysis: (i) Pooled ordinary least squares (POLS); (ii) Fixed Effects Model (FEM); and (iii) Random Effects Model (REM). The model's choice depends on the characteristics of the data and their inherent limitations (Fávero, 2015). Gujarati and Porter (2011) argue that it is possible to evaluate the most appropriate model, using the following specific tests: (a) Chow test - POLS versus FEM; (b) Breusch-Pagan LM test - POLS versus REM; and (c) Hausman test - FEM versus REM.

This paper develops three models to explain the influence of ANS regulation variables on operators' leverage. The following variables are treated as dependent variables: Book Leverage (BL), Short-term debt (STD), and Long-term debt (LTD). We use standard independent variables that can be found in both classical and empirical studies (see Table 1). We also add the regulatory variables described in Table 4. We choose the one-way FEM model in accordance with the results from the Chow, Breusch-Godfrey, and Hausman test. The three estimated models are as follows:

\begin{tabular}{|c|c|}
\hline $\begin{aligned} B L_{i t}=\alpha_{i}+\beta_{1} \times & T_{A N N_{i t}+\beta_{2} \times O P S S_{i t}+\beta_{3} \times P R O_{i t}+\beta_{4} \times G R O W_{i t}+\beta_{5} \times S I N_{i t}+\beta_{6}} \\
& \times N D T S_{i t}+\beta_{7} \times R I S_{i t}+\beta_{8} \times A N T_{i t}+\beta_{9} \times D E P_{i t}+\beta_{10} \times A A B_{i t}+\beta_{11} \\
& \times C O L_{i t}+\beta_{12} \times A R C 1_{i t}+\beta_{13} \times A R C 2_{i t}+\beta_{14} \times A R C 3_{i t}+\beta_{15} \times A R C 4_{i t} \\
& +\beta_{16} \times A R C 5_{i t}+\beta_{17} \times S H P I_{i t}+\beta_{18} \times A N S R_{i t}+\beta_{19} \times F D_{i t}+\beta_{20} \times T A X_{i t} \\
& +\varepsilon_{i t}\end{aligned}$ & (1) \\
\hline $\begin{aligned} \operatorname{STD}_{i t}=\alpha_{i}+\beta_{1} & \times T N_{i t}+\beta_{2} \times O P S S_{i t}+\beta_{3} \times P R O_{i t}+\beta_{4} \times G R O W_{i t}+\beta_{5} \times S I N_{i t}+\beta_{6} \\
& \times N D T S_{i t}+\beta_{7} \times R I S_{i t}+\beta_{8} \times A N T_{i t}+\beta_{9} \times D E P_{i t}+\beta_{10} \times A A B_{i t}+\beta_{11} \\
& \times C O L_{i t}+\beta_{12} \times A R C 1_{i t}+\beta_{13} \times A R C 2_{i t}+\beta_{14} \times A R C 3_{i t}+\beta_{15} \times A R C 4_{i t} \\
& +\beta_{16} \times A R C 5_{i t}+\beta_{17} \times S H P I_{i t}+\beta_{18} \times A N S R_{i t}+\beta_{19} \times F D_{i t}+\beta_{20} \times T A X_{i t} \\
& +\varepsilon_{i t}\end{aligned}$ & (2) \\
\hline $\begin{aligned} L_{T D}=\alpha_{i}+\beta_{1} & \times \text { TAN }_{i t}+\beta_{2} \times \text { OPSS }_{i t}+\beta_{3} \times P R O_{i t}+\beta_{4} \times G R O W_{i t}+\beta_{5} \times S I N_{i t}+\beta_{6} \\
& \times \text { NDTS }_{i t}+\beta_{7} \times R I S_{i t}+\beta_{8} \times A N T_{i t}+\beta_{9} \times D E P_{i t}+\beta_{10} \times A A B_{i t}+\beta_{11} \\
& \times C O L_{i t}+\beta_{12} \times A R C 1_{i t}+\beta_{13} \times A R C 2_{i t}+\beta_{14} \times A R C 3_{i t}+\beta_{15} \times A R C 4_{i t} \\
& +\beta_{16} \times A R C 5_{i t}+\beta_{17} \times S H P I_{i t}+\beta_{18} \times A N S R_{i t}+\beta_{19} \times F D_{i t}+\beta_{20} \times T A X_{i t} \\
& +\varepsilon_{i t}\end{aligned}$ & (3) \\
\hline
\end{tabular}

where $\alpha_{i}$ represents the unobserved time-invariant individual effects, $\varepsilon$ denotes the error term, and $i$ and $t$ are the subscripts that denote companies and time respectively.

We run the panel regression with $\mathrm{R}$ version 3.4.2. To ensure that the estimators are Best Linear Unbiased Estimators (BLUE), we evaluate normality, homoskedasticity, and the absence of serial correlation by using the Anderson-Darling, the Breusch-Pagan, and the Durbin-Watson tests respectively, as recommended by Fávero (2015) and Gujarati and Porter (2011). To avoid issues with 
multicollinearity, we rely mainly on Variance Inflation Factors (VIF). While we also examine correlation coefficients, we are aware that such coefficients are less informative when the number of variables in the model is high. In presence of heteroskedasticity and serial correlation, we employ the Arellano model (1993 cited by Arellano, 2003) to correct such dysfunctions and Driscoll and Kraay's covariance matrix (1998) Following Gujarati and Porter (2011), we use both the adjusted squared-R and the F-test to assess the overall goodness of fit of the estimated models.

\section{ANALYSIS AND DISCUSSION OF RESULTS}

\subsection{Dental cooperatives}

This subsection analyzes the effects of regulatory variables on dental cooperatives debt levels. Table 6 displays the regression results from the estimated models (1), (2), and (3). The analyses show that the FEM specification is preferred for all independent variables. Since fixed effects regression removes the bias from omitted time-invariant variables, slow-moving or time-invariant predictors are collinear with fixed effects. Consequently, the variables $A A B, A R C 1$, and ARC2 needed to be removed from the model. The adjusted squared-R shows how much of the variation is explained by our model. Since our panel is mostly cross-sectional (large number of organizations and small and fixed number of years), the variation is rather small. Moreover, the package plm in $R$ provides the adjusted squared- $R$ for the projected model, which does not include the dummies from the individual effects. Including the dummies within the model greatly increases the adjusted squared-R (about $80 \%$ ).

The three models exhibited heteroskedasticity and autocorrelation. In presence of these two effects, we can obtain heteroskedasticity and autocorrelation consistent standard errors using robust variance-covariance matrices. Stock and Watson (2008) posit that the original White's covariance matrix is inconsistent for cross-sectional panel (fixed number of periods and large number of organizations). Consistent with their results, we use the Arellano version of the covariance matrix. Still, the models (1) and (3) also show cross-sectional dependence. We then use Driscoll and Kraay's covariance matrix (1998), which is robust to cross-sectional dependence. Since the assumptions of linear estimators are violated, we do not need to control for residuals normality. Furthermore, we can assume that asymptotic properties of normality hold, considering our sample size.

Not surprisingly, OPS registered after the creation of the ANS experience a negative impact on their leverage level (H8). As for the firm's operating region, only variables ARC3 and ARC4 have a significant impact on debt levels. In Region 3, composed of any single state except for São Paulo, operators exhibit a similar leverage level, as well as a smaller proportion of short-term debt. Operators in Region 4, which consists of Belo Horizonte, São Paulo, Rio de Janeiro, and Brasília or Curitiba or Porto Alegre, tend also to be lower levered. 
Table 6. Regression results of estimated models for dental cooperatives.

\begin{tabular}{|c|c|c|c|c|c|c|}
\hline Variable Y & \multicolumn{2}{|l|}{ BL } & \multicolumn{2}{|l|}{ STD } & \multicolumn{2}{|l|}{ LTD } \\
\hline Equation & \multicolumn{2}{|l|}{1} & \multicolumn{2}{|l|}{2} & \multicolumn{2}{|l|}{3} \\
\hline Model & \multicolumn{2}{|l|}{ FEM } & \multicolumn{2}{|l|}{ FEM } & \multicolumn{2}{|l|}{ FEM } \\
\hline Variable & Coefficient & P-value & Coefficient & P-value & Coefficient & P-value \\
\hline RIS & $-0,08$ & $0,00 * * *$ & $-0,13$ & $\mathbf{0 , 0 0 * * *}$ & 0,05 & $0,00 * * *$ \\
\hline PRO & $-0,35$ & $0,00 * * *$ & 0,12 & 0,14 & $-0,47$ & $0,00 * * *$ \\
\hline TAN & $-0,32$ & $0,00 * * *$ & $-0,39$ & $0,00 * * *$ & 0,07 & 0,11 \\
\hline SIN & 0,02 & 0,93 & $-0,35$ & 0,31 & 0,37 & $0,03 * *$ \\
\hline OPSS & $-0,02$ & $0,05^{*}$ & 0,03 & 0,23 & $-0,05$ & $0,00 * * *$ \\
\hline GROW & 0,02 & 0,47 & $-0,07$ & $0,00 * * *$ & 0,08 & $0,02 * *$ \\
\hline TAX & $-1,41$ & $0,01 * *$ & 0,08 & 0,84 & $-1,50$ & $0,06^{*}$ \\
\hline NDTS & 0,53 & 0,11 & $-0,64$ & 0,13 & 0,11 & 0,70 \\
\hline ANSR & $-0,09$ & $\mathbf{0 , 0 0 * * *}$ & 0,05 & 0,16 & $-0,05$ & $0,04 * *$ \\
\hline \multicolumn{7}{|l|}{ ARC1 } \\
\hline \multicolumn{7}{|l|}{\begin{tabular}{|l|} 
ARC2 \\
\end{tabular}} \\
\hline ARC3 & $-0,05$ & $0,01 * *$ & 0,01 & 0,55 & $-0,06$ & $0,02 * *$ \\
\hline ARC4 & $-0,06$ & $0,01 * *$ & 0,03 & 0,15 & $-0,09$ & $0,00 * * *$ \\
\hline ARC5 & $-0,01$ & 0,71 & 0,01 & 0,51 & 0,00 & 0,71 \\
\hline FD & $-0,18$ & $\mathbf{0 , 0 0 * * *}$ & 0,44 & $\mathbf{0 , 0 0} * * *$ & $-0,62$ & $0,00 * * *$ \\
\hline \multicolumn{7}{|l|}{$\mathrm{AAB}$} \\
\hline SHPI & $-0,01$ & 0,62 & 0,00 & 0,89 & $-0,01$ & 0,44 \\
\hline $\mathrm{COL}$ & $\mathbf{0 , 0 7}$ & $\mathbf{0 , 0 3 * *}$ & $-0,00$ & 0,96 & 0,07 & $0,00 * * *$ \\
\hline ANT & 0,16 & $\mathbf{0 , 0 0 * * *}$ & 0,05 & 0,27 & 0,11 & $0,00 * * *$ \\
\hline \multirow[t]{6}{*}{ DEP } & 0,09 & 0,11 & 0,07 & 0,37 & 0,02 & 0,75 \\
\hline & Within Adj. $\mathrm{R}^{2}$ & $22,1 \%$ & Within Adj. $\mathrm{R}^{2}$ & $52 \%$ & Within Adj. $\mathrm{R}^{2}$ & $8,6 \%$ \\
\hline & F-test & $20,04^{* * *}$ & F-test & $54,22^{* * *}$ & F-test & $11,90^{* * *}$ \\
\hline & Anderson-Darling & $10,31^{* * *}$ & Anderson-Darling & $10,64^{* * *}$ & Anderson-Darling & $10,2^{* * *}$ \\
\hline & Breusch-Pagan & $71,1^{* * *}$ & Breusch-Pagan & $95,5^{* * *}$ & Breusch-Pagan & $103.8^{* * *}$ \\
\hline & Durbin-Watson & $1,66^{* * *}$ & Durbin-Watson & $1,68^{* * *}$ & Durbin-Watson & $1,49^{* * *}$ \\
\hline
\end{tabular}

Note: *P-Value $<0.1 ; *$ P-Value $<0.05 ; * * *$ P-Value $<0.01$

The variable FD indicates that operators that underwent fiscal management regime at some point tend to have higher debt ratios and longer debt maturities, thus contrasting with the conservative approach we previously assumed (H7). The estimated positive coefficients with respect to the variable $\mathrm{COL}$ show that higher proportions of collective plans tend to increase both firms' leverage and long-term debt (H3). Similarly, high proportions of old contracts are positively related to debt, as evidenced by the variable ANT (H1). The summary of the variables that have a significant impact ( $p$-value below 0.05) on debt levels and their effects is shown in Figure 1. 


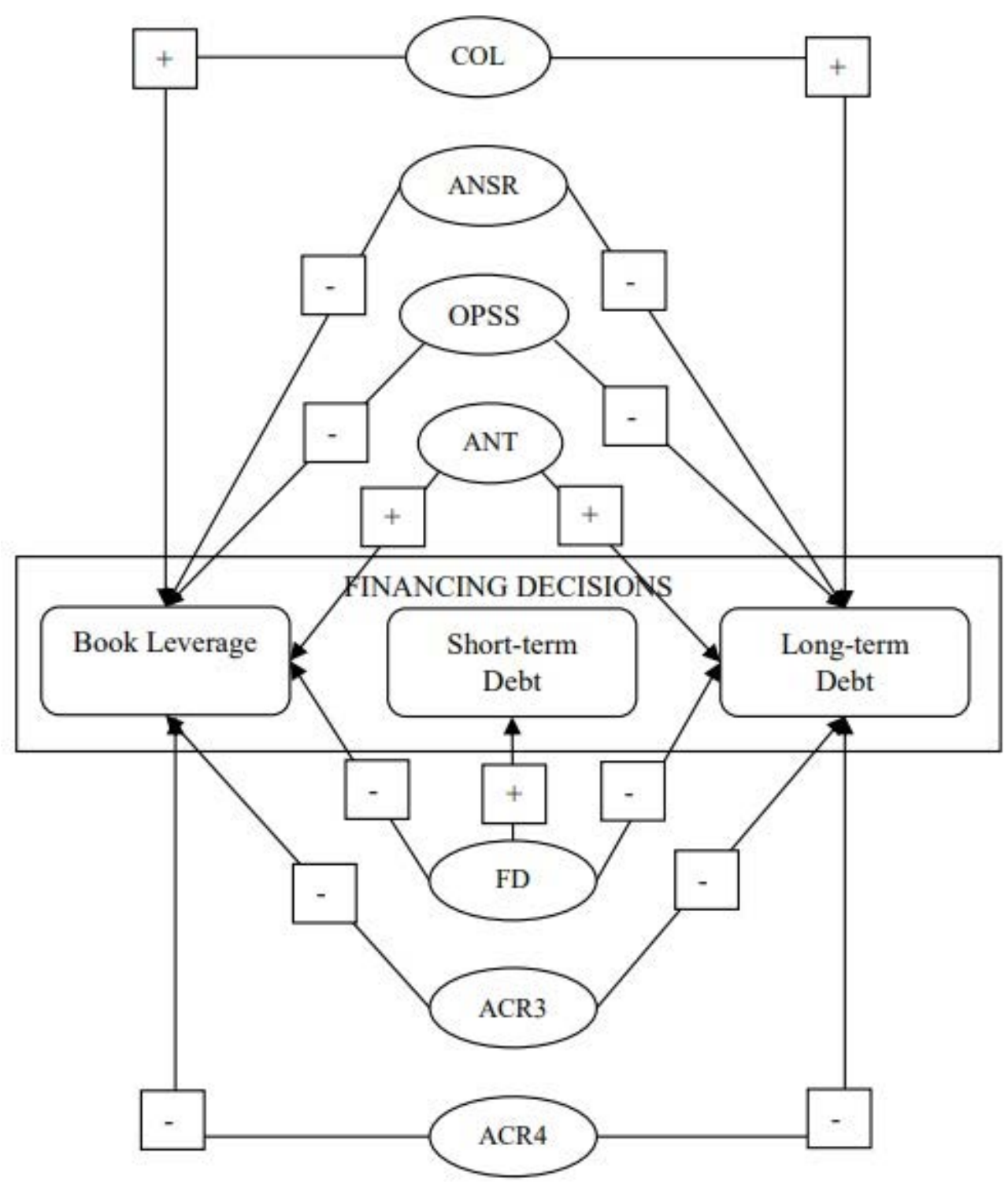

Figure 1. Significant relationships $(p$-value $<0.05$ ) between regulatory variables and dental cooperatives debt levels.

\subsection{Group dentistry}

This subsection analyzes the effects of regulatory variables on group dentistry operators' debt levels. Table 7 presents the results of the estimated models for group dentistry debt levels. The analysis shows that the REM specification is preferred for BL and LTD, while fixed effects are preferred for STD. We employed the same research steps reported in the last section in order to solve problems related to heteroskedasticity and autocorrelation. Notice that no variables were collinear with the fixed effects this time, thus suggesting that $A A B, A R C 1$, and $A R C 2$ are more dispersed over time for operators in the dentistry group. The results are very similar to those observed for dental cooperatives with respect to the following variables: ANSR (H8), ARC3 (H5), ANT (H1), and COL (H3). 
Table 7. Regression results of estimated models for group dentistry.

\begin{tabular}{|c|c|c|c|c|c|c|}
\hline Variable Y & \multicolumn{2}{|l|}{ BL } & \multicolumn{2}{|l|}{ STD } & \multicolumn{2}{|l|}{ LTD } \\
\hline Equation & \multicolumn{2}{|l|}{1} & \multicolumn{2}{|l|}{2} & \multicolumn{2}{|l|}{3} \\
\hline Model & \multicolumn{2}{|l|}{ REM } & \multicolumn{2}{|l|}{ FEM } & \multicolumn{2}{|l|}{ REM } \\
\hline Variable & Coefficient & P-value & Coefficient & P-value & Coefficient & P-value \\
\hline (Intercept) & 0,75 & $0,00 * * *$ & & & $-0,22$ & $0,04 * *$ \\
\hline RIS & $-0,15$ & $0,00 * * *$ & $-0,15$ & $\mathbf{0 , 0 0 * * *}$ & 0,00 & 0,63 \\
\hline PRO & $-0,29$ & $0,00 * * * *$ & $-0,10$ & 0,27 & $-0,13$ & $0,07 *$ \\
\hline TAN & $-0,30$ & $0,00 * * *$ & $-0,44$ & $0,00 * * *$ & $\mathbf{0 , 1 3}$ & $0,02 * *$ \\
\hline SIN & $-0,38$ & $0,02 * *$ & $-0,59$ & $0,00 * * *$ & 0,22 & $0,09 *$ \\
\hline OPSS & 0,01 & 0,16 & $-0,02$ & 0,40 & 0,02 & $0,00^{* * * *}$ \\
\hline GROW & $-0,03$ & 0,32 & 0,01 & 0,57 & $-0,03$ & 0,15 \\
\hline TAX & 0,05 & 0,81 & 0,08 & 0,78 & $-0,04$ & 0,89 \\
\hline NDTS & 0,20 & 0,54 & $-0,11$ & 0,79 & 0,41 & 0,28 \\
\hline ANSR & 0,03 & 0,26 & $-0,08$ & $0,05^{* *}$ & 0,00 & 0,96 \\
\hline ARC1 & $-0,13$ & $0,04 * *$ & 0,02 & 0,56 & $-0,15$ & $0,00 * * *$ \\
\hline ARC2 & 0,02 & 0,85 & 0,02 & 0,57 & 0,01 & 0,86 \\
\hline ARC3 & $-0,14$ & $0,02 * *$ & $-0,08$ & 0,25 & $-0,09$ & $0,07 *$ \\
\hline ARC4 & 0,02 & 0,31 & 0,03 & 0,24 & $-0,00$ & 0,86 \\
\hline ARC5 & $-0,05$ & $0,01 * *$ & $-0,04$ & $0,03 * * *$ & $-0,01$ & 0,45 \\
\hline FD & 0,00 & 0,95 & $-0,13$ & $0,00 * * *$ & $-0,03$ & 0,51 \\
\hline $\mathrm{AAB}$ & $-0,00$ & 0,81 & $-0,00$ & 0,25 & 0,00 & 0,40 \\
\hline SHPI & $-0,04$ & 0,13 & $-0,00$ & 0,91 & $-0,01$ & 0,56 \\
\hline $\mathrm{COL}$ & 0,13 & $0,00 * * *$ & 0,13 & $0,03 * *$ & 0,06 & $0,01 * *$ \\
\hline ANT & $\mathbf{0 , 3 0}$ & $0,00 * * *$ & 0,02 & 0,94 & 0,18 & $0,09 *$ \\
\hline DEP & $-0,04$ & 0,47 & 0,08 & 0,58 & $-0,04$ & 0,31 \\
\hline & Adjusted $\mathrm{R}^{2}$ & $54,4 \%$ & Within Adj. $\mathrm{R}^{2}$ & $20,2 \%$ & Adjusted $\mathrm{R}^{2}$ & $6,9 \%$ \\
\hline & LRT & $700,2^{* * *}$ & F-test & $16,8^{* * *}$ & LRT & $62,16^{* * *}$ \\
\hline & Anderson-Darling & $4,17^{* * *}$ & Anderson-Darling & $17,11^{* * *}$ & Anderson-Darling & $11,29^{* * *}$ \\
\hline & Breusch-Pagan & $47,4^{* * *}$ & Breusch-Pagan & $96,5^{* * *}$ & Breusch-Pagan & $29,7^{*}$ \\
\hline & Durbin-Watson & $1,58^{* * *}$ & Durbin-Watson & $1,74^{* * *}$ & Durbin-Watson & $1,72^{* * *}$ \\
\hline
\end{tabular}

Note: ${ }^{*}$ P-Value $<0.1 ; *$ P-Value $<0.05 ; * * *$ P-Value $<0.01$

Interestingly, operators in Region 1, operating throughout the national territory or in groups of states with the larger numbers of beneficiaries in the country (see Table 3 ), are inclined to reduce their debt. The same situation is observed when we focus on Region 5 (H5). Figure 2 shows a summary of the significant variables ( $p$-value below 0.05 ) and their effects. 
Figure 2. Significant relationships ( $p$-value $<0.05$ ) between regulatory variables and group dentistry debt levels.

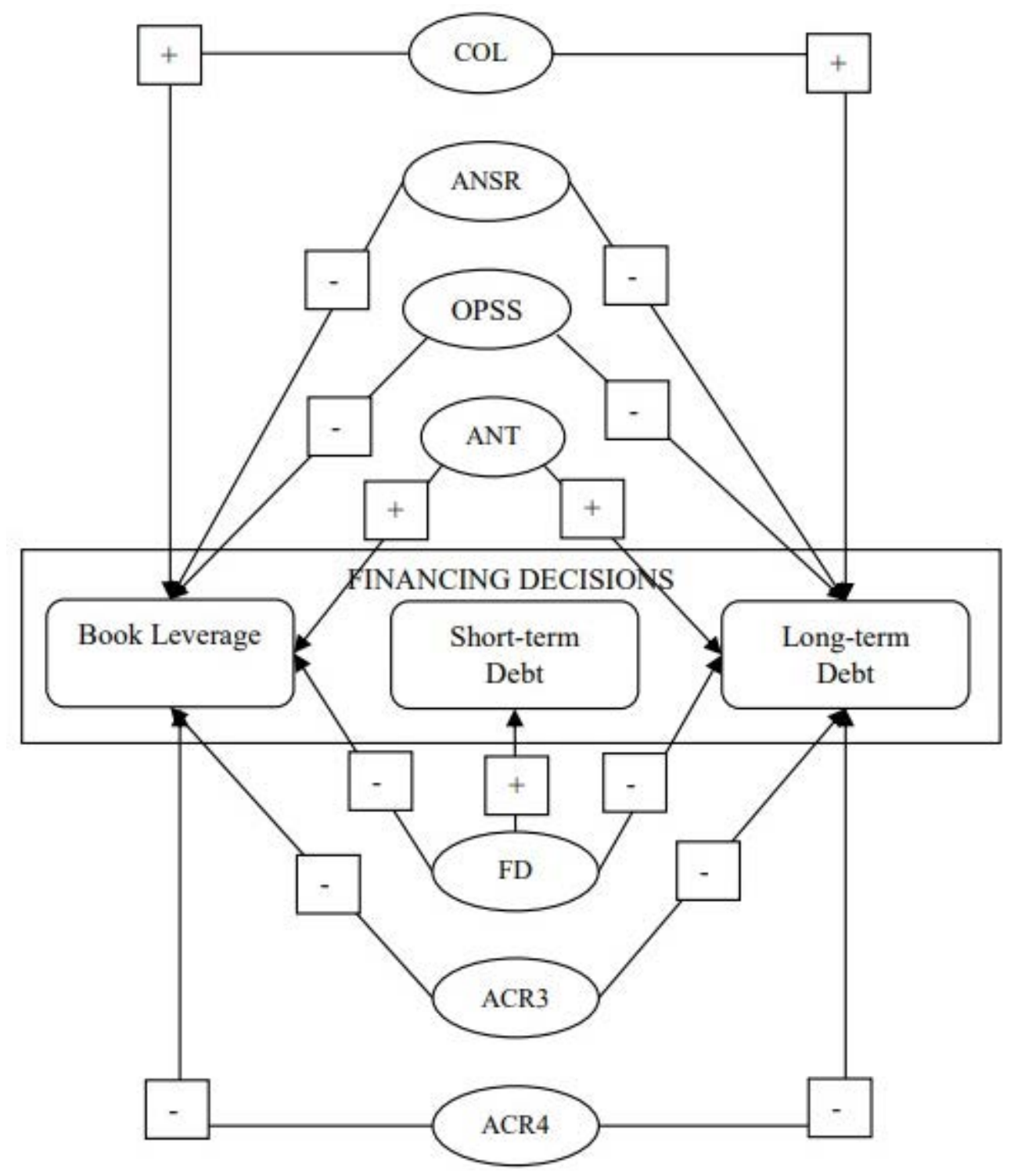

\subsection{Discussion}

The data analysis indicated that several variables related to the ANS regulation influence dental OPS debt levels. There are also several similarities between the two categories under analysis: dental cooperatives and group dentistry, despite the differences in the legal nature of such organizations. When analyzing the organizations size in both categories, we could see that the regulation variable contributes significantly to long-term debt. It confirms the H4. For OPS classified as group dentistry, a positive relationship was found, thus corroborating the results reported by Frank and Goyal (2009), according to which larger organizations tend to obtain liabilities more easily due to diversification and reputation. However, it was found a negative relationship for organizations classified as dental cooperatives. Thus, this result is not support by the literature.

With respect to the ANS Registration (ANSR) variable in both types of OPS that we studied, the registration after the ANS foundation has a negative influence on debt levels. This result confirms H8, and it is in line with Ugá et al. (2008) and Veloso and Malik (2010), who argue that there were no specific limits in the operators' activities until the creation of the ANS, which in turn favored 
those created prior to the 1990s. Such situation can, therefore, be related to the reduced flexibility in financial decisions after the ANS creation, resulting in operators asking for more guarantees from their beneficiaries.

As for the ANT (proportion of old contracts) and COL (percentage of collective plans beneficiaries) variables, the higher proportions of joint and old plans lead to increase debt levels for both categories. These results confirms both $\mathrm{H} 1$ and $\mathrm{H} 3$. This situation can be explained by the fact that these more flexible plans encourage higher profitability, which would imply a lower cost to financing the firm's operations. This finding corroborates that reported by Leal (2014), who said that a tendency of the OPS to opt for joint plans is presented as an example.

Dental health plan operators (OPS) operating in Region 3 are more inclined to reduce their short-term debt. The same result was found for dental cooperatives that operate in Region 4 and for group dentistry OPS operating in Region 1. Such findings may be related to the higher demand from large municipalities (or the country as a whole) for health plans, which would require less level of liabilities (low risk) to be met. In the last two cases, the highest requirement of adjusted net worth (ANW) according to the ANS (2009) could explain this phenomenon. Note that group dentistry operators in Region 5 also experience debts. These results shed lights on the relationship between the regions and leverage level (H5), however it is not possible to conclude anything about the basis underlying the direction of relations.

The regulatory variable FD (fiscal direction) is significant for all three models in dental cooperatives. It shows that cooperatives that underwent the fiscal management regime have higher debt ratios and longer maturities. This may be caused by the fact that operators that undergo such a regime usually have already existing excessive amounts of debt. Interestingly, operators from group dentistry that underwent the same regime tend to have shorter debt maturities. Therefore, it is possible to confirm (totally or partly) the most hypotheses developed in the Section 2.3, except the following ones: $\mathrm{H} 2$ (related to average of ages of beneficiaries - AAB), H6 (related to Supplementary Health Performance Index - SHPI) and H9 (related to dependency correlation - DEP).

\section{FINAL REMARKS}

This paper analyzes the determinants of leverage in dental health plan operators (OPS) and focuses on the effects of regulatory variables. Most of the traditional variables used in the literature and shown in Section 2.1 appear to be significant. Still, in some models, certain classical variables present an estimated coefficient with a divergent signal, differently from those expected from the literature. This situation may be related to the use of a broader concept of leverage, such as that of Rajan and Zingales (1995).

Given that all regulation-related variables are significant in at least one estimated model, it seems that the ANS regulations have affected dental OPS debt levels in different ways. It is important to note that debt maturity also has a huge impact on the significance of such variables. This observation highlights the importance of considering the debt maturity structure when studying corporate leverage, as emphasized by Cavalcanti et al. (2016) and Welch (2011).

The present study offers a range of contributions to the development of the area under investigation. It emphasizes the role of regulation in financial decisions of dental OPS in Brazil, taking into consideration the relationship between regulatory norms and their financial performance. This is in line with several studies, such as those of Silva and Loebel (2016) and Veloso and Malik (2010). Second, this paper finds that traditional determinants are still important indicators of OPS debt levels, even though some of those determinants were found to be not significant. Finally, this paper 
offers new regulatory determinants to explain OPS debt levels, in addition to the traditional variables mentioned in the literature.

Yet, the present study suffers from some limitations: (a) the sample investigated is restricted to OPS public data; and (b) regulation variables are limited due to the data available for calculation, despite our efforts to show otherwise. This is an inherent limitation of this type of investigation, as emphasized by French and Fama (2002).

Future research should test the regulatory variables proposed here in other contexts: with new samples or in different time frames. Moreover, further research could recommend new regulatory variable to explain the debt levels of other dental health plan operators (OPS) categories based on the National Supplementary Health Agency (ANS) classification (2000).

\section{REFERENCES}

AGÊNCIA NACIONAL DE SAÚDE SUPLEMENTAR. (2011). Caderno de Informação da Saúde Suplementar: Beneficiários, Operadoras e Planos Recuperado de http://www.ans.gov.br/ images/stories/noticias/pdf/caderno_de_informa\%C3\%A7\%C3\%A3o_mar_2015_final.pdf.

. (2017). Caderno de Informação da Saúde Suplementar: Beneficiários, Operadoras e Planos - Junho. Recuperado de http://www.ans.gov.br/images/stories/Materiais_para_pesquisa/ Perfil_setor/Caderno_informacao_saude_suplementar/caderno_informacao_junho_2017. pdf.

. (2016) Dados e Indicadores do Setor. Recuperado de http://www.ans.gov.br/perfil-dosetor/dados-e-indicadores-do-setor.

. (2018a) Programa de Qualificação de Operadoras. Recuperado de http://www.ans.gov.br/ planos-de-saude-e-operadoras/informacoes-e-avaliacoes-de-operadoras/qualificacao-ans.

. (2018b) Registro de operadora. Recuperado de http://www.ans.gov.br/planos-de-saudee-operadoras/espaco-da-operadora/registro-e-manutencao-de-operadoras-e-produtos/ registro-de-operadora.

. (2000). Resolução de Diretoria Colegiada - RDC n. 39, de 27 de outubro de 2000. Recuperado de http://www.ans.gov.br/component/ legislacao/?view=legislacao\&task=TextoLei\&format=raw\&id=Mzgw.

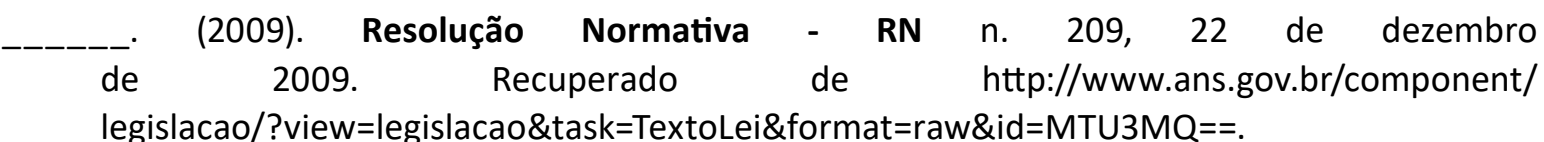

(2018c) Sala de Situação. Recuperado de http://www.ans.gov.br/perfil-do-setor/dados-eindicadores-do-setor/sala-de-situacao.

AN, Z. (2012). Taxation and capital structure: empirical evidence from a quasi-experiment in China. Journal of Corporate Finance, 18(4), 683-689.

ARELLANO, M. (2003). Panel Data Econometrics: Advanced Texts in Econometrics. Oxford, USA: Oxford University Press.

ASSOCIAÇÃO BRASILEIRA DE PLANOS DE SAÚDE. (2015). Custo cresce mais que receita, dizem 
planos. Recuperado de http://blog.abramge.com.br/mundo-corporativo/economia-mercado/ custo-cresce-mais-que-receita-dizem-planos/

AVELAR, E. A. CAVALCANTI, J. M., PEREIRA, H. R., \& BOINA, T. M. (2017). Determinantes da Estrutura de Capital: Um Estudo sobre Empresas Mineiras de Capital Fechado. Revista Evidenciação Contábil \& Finanças, 5(2), 23-39.

BABBIE, E. R. (1999). Métodos de pesquisas de survey. Belo Horizonte, MG: Editora UFMG.

BALDASSARE, R. M. (2014). Análise do desempenho econômico-financeiro de operadoras de planos de saúde no mercado de saúde suplementar brasileiro. Dissertação de Mestrado, Fundação Getúlio Vargas, São Paulo, SP, Brasil.

BARDIN, L. (2002). Análise de conteúdo. Lisboa: Edições 70.

BRAGANÇA, C. G. (2017). Liquidação de operadoras de planos de assistência à saúde no Brasil. Dissertação de Mestrado, Universidade Federal de Minas Gerais, Belo Horizonte, MG, Brasil.

BRITO, G. A., CORRAR, L. C., \& BATISTELLA, F. D. (2007) Fatores determinantes da estrutura de capital das maiores empresas que atuam no Brasil. Revista Contabilidade \& Finanças, 18(43), 9-19.

CAVALCANTI, J. M. M., CASTRO, S. L., AVELAR, E. A., LAZO, R. P, \& MÓL, A. L. R. (2016). Financial debt stratification and capital structure determinants of companies listed in the BM\&FBOVESPA. Revista de Gestão, Finanças e Contabilidade, 6(3), 125-142.

CERETTA, P. S., VIEIRA, K. M., FONSECA, J. L., \& TRINDADE, L. L. (2009). Determinantes da estrutura de capital: uma análise de dados em painel de empresas pertencentes ao lbovespa no período de 1995 a 2007. Revista de Gestão USP, 16(4), 29-43.

CORREA, C. A., BASSO, L. F. C., \& NAKAMURA, W. T. (2013). A estrutura de capital das maiores empresas brasileiras: análise empírica das teorias de pecking order e trade-off, usando panel data. Revista de Administração Mackenzie, 14(4), 106-133.

COSTA, N. R. (2008). O regime regulatório e o mercado de planos de saúde no Brasil. Ciência \& Saúde Coletiva, 13(5), 1453-1462.

DRISCOLL, J. C., \& KRAAY, A. C. (1998). Consistent Covariance Matrix Estimation with Spatially Dependent Panel Data. Review of Economics and Statistics, 80(4), 549-560.

ENGBERG, J., WHOLEY, D., FELDMAN, R., \& CHRISTIANSON, J. B. (2004). The effect of mergers on firms' costs: evidence from the HMO industry. The Quarterly Review of Economics and Finance, 44(4), 574-600.

FAMA, E. F., \& FRENCH, K. R. (2005). Financing decisions: who issues stock? Journal of Financial Economics, 76(3), 549-582.

. (2002). Testing Trade-Off and Pecking Order Predictions About Dividends and Debt. The Review of Financial Studies, 15(1), 1-33.

FÁVERO, L. P. (2015). Análise de Dados: Modelos de Regressão com Excel ${ }^{\circledR}$, Stata ${ }^{\circledR}$ e SPSS ${ }^{\circledR}$. Rio de Janeiro: Elsevier. 
FERNANDES, F., FERREIRA, M. E., \& RODRIGUES, E. R. (2014). Análise de rentabilidade utilizando o modelo Dupont: estudo de caso em uma operadora de planos de saúde. Revista de Gestão em Sistemas de Saúde, 3(2), 30-44.

FORTE, D., BARROS, L. A., \& NAKAMURA, W. T. (2013). Determinants of the capital structure of small and medium sized Brazilian enterprises. Business Administration Review, 10(3), 347-369.

FRANK, M. Z., \& GOYAL, V. K. (2009). Capital Structure Decisions: Which Factors are Reliably Important?. Financial Management, 38(1),1-38.

GELBECK, E. R., SANTOS, A., IUDÍCIBUS, S., \& MARTINS, E. (2018). Manual de contabilidade societária: aplicável a todas as sociedades: de acordo com as normas internacionais e do CPC. (3a ed.) São Paulo, SP: Atlas.

GUJARATI, D., \& PORTER, D. C. (2011). Econometria básica. (5a ed.). Porto Alegre, RS: AMGH.

HARRIS, M., \& RAVIV, A. (1991). The Theory of Capital Structure. The Journal of Finance, 46(1), 297-355.

KUDLAWICZ, C., STEINER P. J., NETO, \& FREGA, J. R. (2015). Homogeneidade e rentabilidade: o caso das operadoras de planos de saúde. Revista de Informação Contábil, 9(1), 50-67.

LEAL, R. M. (2014). O mercado de saúde suplementar no Brasil: regulação e resultados econômicos dos planos privados de saúde. In Anais da 8a Jornada de Estudos de Regulação, Rio de Janeiro, RJ.

LEI N. 9.961, DE 28 DE JANEIRO DE 2000. (2000). Cria a Agência Nacional de Saúde Suplementar - ANS e dá outras providências. Recuperado de http://www.planalto.gov.br/ccivil_03/ constituicao/constituicaocompilado.htm.

LEI N. 9.656, DE 3 DE JUNHO DE 1998. (1998). Dispõe sobre os planos e seguros privados de assistência à saúde. Recuperado de http://www.planalto.gov.br/ccivil_03/Leis/L9656.htm.

LEMMON, M. L., \& ZENDER, J. F. (2010). Debt Capacity and Tests of Capital Structure Theories. Journal of Financial and Quantitative Analysis, 45(5), 1161-1187.

MALHOTRA, N. K., \& BIRKS, D. F. (2007) Marketing Research: An Applied Approach. (3a European ed.). Harlow: Prentice Hall.

MENEZES, J. P. C. B., SANT'ANA, N. L. S., FERREIRA, A. C., SILVA, S. A. L., \& SOUZA, A. A. (2016). Estudo sobre o capital de giro das operadoras de planos de saúde atuantes no Vale do Mucuri - MG. Revista Eletrônica das Faculdades Integradas Vianna Júnior, 7(2), 202-228.

PEROBELLI, F. F. C., \& FAMA, R. (2002) Determinantes da estrutura de capital: aplicação a empresas de capital aberto brasileiras. Revista de Administração, 37(3), 33-46.

PINHEIRO, I. C. B., PELEIAS, I. V., SILVA, A. F., \& MARTINS, E. (2015). Efeitos da regulação econômicofinanceira nas estratégias de financiamento das operadoras de planos de saúde. Revista Universo Contábil, 11(2), 108-127.

POHLMANN, M. C., \& IUDICIBUS, S. (2010). Relação entre a tributação do lucro e a estrutura de capital das grandes empresas no Brasil. Revista Contabilidade \& Finanças, 21(53), 1-25. 
RAJAN, R. G., \& ZINGALES, L. (1995). What Do We Know about Capital Structure? Some Evidence from International Data. The Journal of Finance, 50(5), 1421-1460.

ROSS, S. A., WESTERFIELD, R. W., JAFFE, J., \& LAMB, R. (2015). Administração financeira (10a ed.). São Paulo: AMGH.

SILVA, V. V.; LOBEL, E. (2016). Análise do desempenho econômico-financeiro de operadoras de planos privados de saúde do setor brasileiro de saúde. Revista de Administração Hospitalar e Inovação em Saúde,13(3), 1-21.

SILVA, B. N., COSTA, M. A. S., ABBAS, K., \& GALDAMEZ, E. V. C. (2017). Eficiência hospitalar das regiões brasileiras: um estudo por meio da análise envoltória de dados. Revista de Gestão em Sistemas de Saúde, 6(1), 76-91.

STOCK, J. H., \& WATSON, M. W. (2008). Heteroskedasticity-Robust Standard Errors for Fixed Effects Panel Data Regression. Econometrica, 76(1), 155-174.

SUPREMO TRIBUNAL FEDERAL. (2003) Ação direta de inconstitucionalidade (Med. liminar) 1931. Recuperado em 10 de fevereiro, 2017, em: http://www.stf.jus.br/portal/peticaolnicial/ verPeticaolnicial.asp?base=ADIN\&s1=1931\&processo=1931.

TITMAN, S., \& WESSELS, R. (1988). The Determinants of Capital Structure Choice. The Journal of Finance, 43(1), 1-19.

UGÁ, M. A. D., LIMA, C. L. M., PORTElA, M. C., VASCONCEllos, M. M., BARBOSA, P. R., \& GERSCHMAN, S. (2008). Uma análise das operadoras de planos próprios de saúde dos hospitais filantrópicos no Brasil. Cadernos de Saúde Pública, 24(1), 157-168.

VARELLA, D., \& CESCHIN, M. (2014). A saúde dos planos de saúde: os desafios da assistência privada no Brasil. São Paulo: Paralela.

VELOSO, G. G.; MALIK, A. M. (2010). Análise do desempenho econômico-financeiro de empresas de saúde. RAE-eletrônica, 9(1), art. 2, 1-22.

WELCH, I. (2011). Two Common Problems in Capital Structure Research: The Financial-Debt-toAsset Ratio and Issuing Activity Versus Leverage Changes. International Review of Finance, 11(1), 1-17.

XAVIER, D. O. (2017). Variáveis determinantes do desempenho econômico-financeiro de operadoras de planos de saúde. Dissertação de Mestrado, Universidade Federal de Minas Gerais, Belo Horizonte, MG, Brasil. 


\section{AUTHORS}

\section{Ewerton Alex Avelar}

Doctor in Administration from Federal University of Minas Gerais - UFMG.

E-mail: ewertonalexavelar@gmail.com

ORCID: https://orcid.org/0000-0003-2374-8954

\section{Antônio Artur de Souza}

Ph.D. in Management Science from Lancaster University.

E-mail: antonioarturdesouza@gmail.com

ORCID: https://orcid.org/0000-0002-4725-0758

\section{Hudson Fernandes Amaral}

Doctor in Administration from Pierre Mendès France University.

E-mail: hfamaral.cepead@gmail.com

ORCID: https://orcid.org/0000-0001-8455-0285

\section{Jacqueline Braga Paiva Orefici}

Doctor in Administration from Polytechnic University.

E-mail: j.orefici@gmail.com

ORCID: https://orcid.org/0000-0001-5378-4046

\section{Romain Cailleau}

Doctor Student in Administration from Federal University of Minas Gerais - UFMG.

E-mail: rmn.cailleau@gmail.com

ORCID: https://orcid.org/0000-0003-2382-5542

\section{Contribution of authors.}

\begin{tabular}{|c|c|c|c|c|c|}
\hline Contribution & [Author 1] & [Author 2] & [Author 3] & [Author 4] & [Author 5] \\
\hline 1. Definition of research problem & $\sqrt{ }$ & $\mathrm{V}$ & & & \\
\hline $\begin{array}{l}\text { 2. Development of hypotheses or research } \\
\text { questions (empirical studies) }\end{array}$ & $\sqrt{ }$ & V & & & \\
\hline $\begin{array}{l}\text { 3. Development of theoretical propositions } \\
\text { (theoretical work) }\end{array}$ & $\sqrt{ }$ & $\sqrt{ }$ & $\sqrt{ }$ & & \\
\hline $\begin{array}{l}\text { 4. Theoretical foundation / Literature } \\
\text { review }\end{array}$ & $\sqrt{ }$ & $\sqrt{ }$ & $\sqrt{ }$ & & \\
\hline 5. Definition of methodological procedures & $\mathrm{V}$ & $\sqrt{ }$ & $\sqrt{ }$ & & $\mathrm{v}$ \\
\hline 6. Data collection & V & & & & V \\
\hline 7. Statistical analysis & $\mathrm{V}$ & & & $\mathrm{V}$ & $\sqrt{ }$ \\
\hline 8. Analysis and interpretation of data & $\sqrt{ }$ & $\sqrt{ }$ & & $\mathrm{V}$ & $\mathrm{v}$ \\
\hline 9. Critical revision of the manuscript & $\mathrm{v}$ & V & v & V & \\
\hline 10. Manuscript writing & $\mathrm{V}$ & & & $\mathrm{V}$ & $\mathrm{v}$ \\
\hline
\end{tabular}

